\title{
The importance of habitat islands in the preservation of relict xerothermic and calcicolous epigeic lichens based on the example of the "Ostnicowe Parowy Gruczna" nature reserve ( $\mathrm{N}$ Poland)
}

\author{
Mirosława Ceynowa-Gieldon, Edyta Adamska*, Dariusz Kamiński
}

\begin{abstract}
Nicolaus Copernicus University, Faculty of Biology and Environmental Protection, Chair of Geobotany
\end{abstract} and Landscape Planning, Lwowska 1,87-100 Toruń, Poland, *e-mail: adamska@umk.pl

Received: 24 March 2017/Accepted: 31 May 2017

\begin{abstract}
The objective of this paper is to discuss the role of environmental islands isolated in the agricultural landscape in the preservation of xerothermic and calcicolous epigeic lichens. The site of lichens associated with relict steppe vegetation, rare in northern Poland, has been preserved in the reserve "Ostnicowe Parowy Gruczna". The list of lichen taxa identified in the study area comprises 16 species that are very rare in lowland, e.g. Gyalolechia fulgens, Heppia adglutinata, Squamarina lentigera, Endocarpon pusillum, Gyalolechia bracteata, Placidium squamulosum and Toninia sedifolia. In many places, the lichens associated with dry grasslands become extinct despite the optimum light conditions. These lichen species are sensitive to the impact of agriculture. Preservation of epigeic lichens' localities is possible in specific habitat conditions when they are isolated from surface runoff of fertile farm water.
\end{abstract}

Key words: terricolous lichens, relicts, anthropogenic changes, dry grasslands lichens, habitat island.

\section{Introduction}

The most favourable conditions for the growth and spread of xerothermic and calcicolous epigeic (terricolous) lichens prevailed in the early postglacial periods, before the development of forest communities. At that time, not only the climate, but also large areas of bare soil favoured the development of lichens. During the subsequent dominance of forest communities, epigeic lichens could thrive only over small areas, often on eroded slopes of river valleys. Deforestation of lands carried out by man created habitats supporting terrestrial heliophytes under conditions of competition with shadow-preferring forest plant communities. As a result, common species encountered on dunes, on the edges of forests and within thinned forest stands were spreading. For this reason, rare species with a strongly fragmented geographic range require more comprehensive studies and observations. Species susceptible to changes in the soil fertility associated with intensification of agriculture require special attention (Ceynowa, 1969; CeynowaGiełdon et al., 2004).

Epigeic xerothermophilous lichens, often reported from upland regions of southern Poland (Cieśliński, 1979, 1981; Nowak, 1961; Olech, 1985; Tobolewski, 1958; Wójciak, 1987), are among less common components of the lichen biota in northern lowland Poland (Glanc, 1964; Fałtynowicz, 1992; Filipek, 1974; Tobolewski, 1962; Wieczorek \& Schiefelbein, 2014). Data on lichens occurring on xerothermic grasslands outside Poland are provided e.g. by Löbel et al. (2006), Otte \& Rätzel (2004) and Schiefelbein (2002). In Poland, scattered localities of xerocontinental lichens were described from the lower Vistula (Ceynowa, 
1969; Ceynowa-Giełdon, 1993, 1997, 2001; CeynowaGiełdon \& Glazik, 1994; Ceynowa-Giełdon et al., 2004).

Xerothermophilous lichens belong to the group of considerably threatened organisms in Poland (Cieśliński et al., 2006). According to Cieśliński \& Czyżewska (1992), exploitation of rock materials and afforestation of grasslands are major risk factors.

The objective of this paper was to present the results of the lichenological research carried out in the "Ostnicowe Parowy Gruczna" nature reserve in 2003 as well as to answer the question why this community of lichens has survived only over a small area in this reserve and not in the other parts of the lower Vistula River? Data on the occurrence of xerothermophilous species in the Polish Lowlands, referred to as a relict site, represent a valuable reference material for further observations of the dynamics of changes in the distribution of these taxa in time and space in Poland.

\section{The study area}

The described site of epigeic lichens is located within the boundaries of the "Ostnicowe Parowy Gruczna" nature reserve. The nature reserve with an area of 23.79 ha was created in 1999 to preserve varied erosional clefts on the slopes of the Vistula River valley with unique xerothermic vegetation (Rozporządzenie, 1999). It is located near the village of Gruczno, about $30 \mathrm{~km}$ north-east of the city of Bydgoszcz (ATPOL CB98, CC08; Fig. 1). The nature reserve area resembles an irregular strip with a length of $1.5 \mathrm{~km}$ and a width of 100-400 m. The steep slope of the Świecie Plateau scarp rises here ca. $40 \mathrm{~m}$ above the floor of the Fordon Valley, which is the first section in the Lower Vistula valley. The diverse morphology of the slopes results in diverse habitats with varied exposure (southern, eastern and north-eastern) and inclination of slopes ranging from $15^{\circ}$ to $40^{\circ}$. Slopes consist of sand, loam and clay with a high content of calcium carbonate (Ceynowa-Giełdon \& Waldon, 2001). Arable fields and buildings of the Gruczno village are located in the immediate vicinity of the nature reserve (Adamska et al., 2015).

\section{Methods}

The lichenological fieldwork was carried out in the "Ostnicowe Parowy Gruczna" nature reserve on the 18th September 2003. To obtain data on the occurrence of xerothermophilous lichens, four relevés were made using the generally

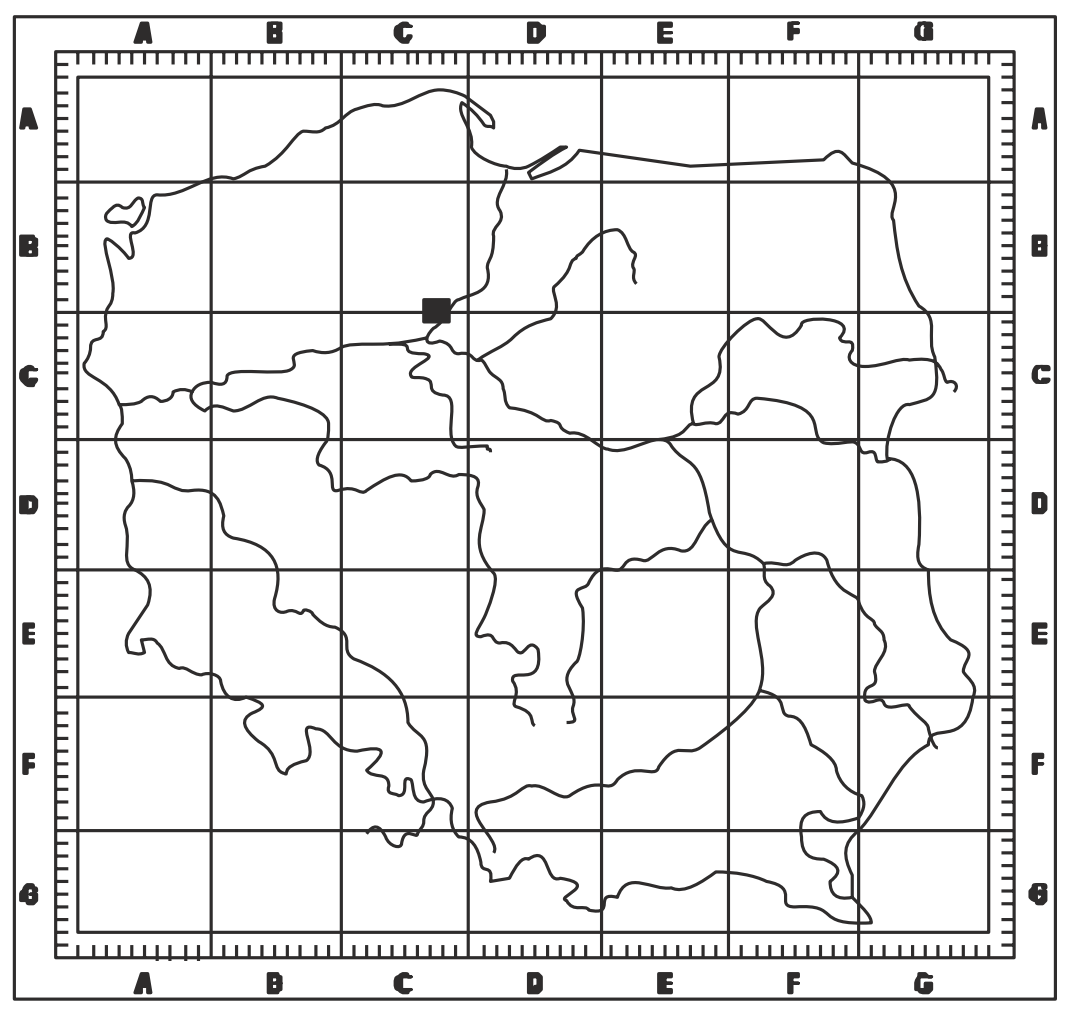

Figure 1. Location of research area in the grid of ATPOL squares 
accepted Braun-Blanquet method. Taxonomic identification of the collected lichen thalli was based, inter alia, on the following studies: Nowak \& Tobolewski (1975), Wirth (1995), Purvis et al. 1994 and Smith et al. (2009).

The nomenclature of lichen species follows mainly Fałtynowicz \& Kossowska (2016), Index Fungorum (2017).

Categories of threat were determined according to the Red List of Threatened Lichens in Poland according to Cieśliński et al. (2006): CR - Critically Endangered, EN - Endangered, VU - Vulnerable, NT - Near Threatened, and the protection status according to Regulation of the Minister of the Environment (Rozporządzenie, 2014). The identified material was deposited in the Herbarium of the Department of Geobotany and Landscape Planning, Nicolaus Copernicus University in Torun (TRN). The location of sites was based on the grid of ATPOL squares according to Zając (1978).

\section{Results}

A total of 16 lichen species were identified at the study site in the community of initial xerothermic grassland. Those were mostly epigeic lichens (Table 1).

Table 1. Toninio-Psoretum decipientis Stodiek 1937 fulgensietum bracteatae

\begin{tabular}{|c|c|c|c|c|c|}
\hline \multirow{2}{*}{$\begin{array}{l}\text { Location; date } \\
\text { No. of reléve }\end{array}$} & \multicolumn{4}{|c|}{ Gruczno 18.09.2003 } & \multirow{2}{*}{$\begin{array}{l}\text { Saxony* } \\
\text { Constancy } \\
11 \text { reléves }\end{array}$} \\
\hline & 1 & 2 & 3 & 4 & \\
\hline \multicolumn{6}{|l|}{ Ch Ass } \\
\hline Gyalolechia fulgens & . & . & + & . & $\mathrm{I}^{1}$ \\
\hline \multicolumn{6}{|l|}{ D Ass } \\
\hline Gyalolechia bracteata & 1 & + & + & + & $\mathrm{V}^{+-3}$ \\
\hline \multicolumn{6}{|c|}{$\begin{array}{l}\text { Ch Toninion caeruleonigricantis Hadač } 1948 \text {, } \\
\text { Psoretalia decipientis Mattic } \\
\text { ex Follmann 1974: }\end{array}$} \\
\hline Toninia sedifolia & 2 & 1 & 1 & + & $\mathrm{IV}^{1}-2$ \\
\hline Cladonia subrangiformis & 1 & . & + & + & $\mathrm{I}^{1}$ \\
\hline Encalypta vulgaris & 1 & + & . & + & $\mathrm{III}^{+-2}$ \\
\hline Squamarina lentigera & . & . & . & + & $\mathrm{I}^{1}$ \\
\hline Placidium squamulosum & . & . & . & + & $\mathrm{IV}^{+-1}$ \\
\hline Cladonia pocillum & + & . & . & . & $\mathrm{II}^{1-2}$ \\
\hline Heppia adglutinata & . & $(+)$ & . & . & . \\
\hline Psora decipiens & . & . & . & . & $\mathrm{IV}^{2}$ \\
\hline \multicolumn{6}{|c|}{$\begin{array}{l}\text { Ch Psoretea decipientis Mattick ex Follmann } 1974 \\
\text { emend. Drehwald 1993: }\end{array}$} \\
\hline Tortiella inclinata & . & . & . & . & $\mathrm{IV}^{+-2}$ \\
\hline Barbula fallax & . & & & & $\mathrm{I}^{+}$ \\
\hline Barbula convoluta & . & + & . & . & . \\
\hline \multicolumn{6}{|l|}{ Acompanying species: } \\
\hline Blenothallia crispa & 3 & 2 & 2 & . & . \\
\hline Bryum caespiticium & . & 2 & + & 1 & \\
\hline Endocarpon pusillum & 1 & . & + & . & . \\
\hline
\end{tabular}




\begin{tabular}{|c|c|c|c|c|c|}
\hline \multirow{2}{*}{$\begin{array}{c}\text { Location; date } \\
\text { No. of reléve }\end{array}$} & \multicolumn{4}{|c|}{ Gruczno 18.09 .2003} & \multirow{2}{*}{$\begin{array}{c}\text { Saxony* } \\
\text { Constancy } \\
11 \text { reléves }\end{array}$} \\
\hline & 1 & 2 & 3 & 4 & \\
\hline Koeleria glaca & + & . & + & . & . \\
\hline Festuca trachyphylla & . & 2 & . & . & . \\
\hline Tortula ruralis & . & + & + & . & . \\
\hline Stipa joannis & . & . & . & + & . \\
\hline Silene otitis & . & . & . & + & . \\
\hline Thymus pulegioides & . & . & . & . & $\mathrm{II}^{+-2}$ \\
\hline Potentilla neumanniana & . & . & . & . & $\mathrm{II}^{+-2}$ \\
\hline Barbula revolute & . & . & . & . & $\mathrm{II}^{2}$ \\
\hline Sedum acre & . & . & . & . & $\mathrm{II}^{1}$ \\
\hline Peltigera rufescens & . & . & . & . & $\mathrm{II}^{+}$ \\
\hline Festuca ovina & . & . & . & . & $\mathrm{I}^{1-2}$ \\
\hline Sesleria coerulea & . & . & . & . & $\mathrm{I}^{+-2}$ \\
\hline Koeleria pyramidata & . & . & . & . & $\mathrm{I}^{2}$ \\
\hline Campanula rotundifolia & . & . & . & . & $\mathrm{I}^{+-1}$ \\
\hline Brachypodium pinnatum & . & . & . & . & $\mathrm{I}^{1}$ \\
\hline Hypnum lacunosum & . & . & . & . & $\mathrm{I}^{1}$ \\
\hline Ditrichum flexicaule & . & . & . & . & $\mathrm{I}^{1}$ \\
\hline Abietinella abietina & . & . & . & . & $\mathrm{I}^{1}$ \\
\hline Enchylium tenax & . & . & . & . & $\mathrm{I}^{+}$ \\
\hline Diploschistes muscorum & . & . & . & . & $\mathrm{I}^{+}$ \\
\hline Bacidia bagliettoana & . & . & . & . & $\mathrm{I}^{+}$ \\
\hline Circinaria calcarea & . & . & . & . & $\mathrm{I}^{+}$ \\
\hline
\end{tabular}

* Typical variant acc. to Drehwald 1993; area of reléves $=40-60 \mathrm{~cm}^{2}$

They are part of an interesting community developed on the slope of the Vistula River valley in the "Ostnicowe Parowy Gruczna" reserve. This community forms an easily noticeable, colourful, crustaceous mosaic of mosses and lichens on the ground. In terms of the species composition, it resembles phytocoenoses Toninio-Psoretum decipientis fulgensietum bracteatae growing on gypsum and limestone. In the "Ostnicowe Parowy Gruczna" reserve, it has developed only in the form of the subassociation with Gyalolechia bracteata (Hoffm.) A. Massal. and covers a small, sandy area of the eroding slope (Photo 1). The habitat is dry and warm, strongly sunlit. G. bracteata is the most conspicuous component of the community and is often accompanied by Toninia sedifolia (Scop.) Tim- dal, whereas Gyalolechia fulgens (Sw.) Søchting, Frödén $\&$ Arup and Squamarina lentigera (Weber) Poelt, are rarely encountered.

Among the identified 16 lichen species, 7 taxa are on the Red List of Threatened Lichens in Poland (Cieśliński et al., 2006), including one - Gyalolechia fulgens - in the CR category, Heppia adglutinata and Squamarina lentigera - in the EN category, Endocarpon pusillum and Gyalolechia bracteata, - in the VU category, Placidium squamulosum and Toninia sedifolia in the NT category. Four species are legally protected pursuant to the Regulation of the Minister of the Environment (Rozporządzenie, 2014); three of these species are strictly protected: Gyalolechia bracteata. G. fulgens and Squamarina len- 
tigera. However, the complete list of components of the community comprises also other species that are rare in Poland, including not only lichens, but also mosses and vascular plants (Table 1). A smaller contribution of vascular plants in the communities described from Saxony results from the initial nature of the habitat.

A question arises why the described community of lichens survived at the lower Vistula River only over a small area in the "Ostnicowe Parowy Gruczna" nature reserve?

\section{Discussion}

The lichens found in Gruczno: Gyalolechia bracteata, G. fulgens, Squamarina lentigera and Toninia sedifolia are encountered on extremely xerothermic habitats together with Stipa joannis Čel., Scorzonera purpurea L. and other relict species of the vascular flora. The first two of the abovementioned lichen species occur at the lower Vistula River only in the "Ostnicowe Parowy Gruczna" reserve - ATPOL: CC08 (Ceynowa-Giełdon, 2001; Ceynowa-Giełdon \& Glazik, 1994).
On the one hand the nearest localities of Gyalolechia bracteata are located in southern Sweden (Moberg \& Holmåsen, 1992; Santesson, 1993), but on the other, in southern Poland: on the Nida River, in the Kraków-Wielun Upland and further on in the mountains - the Tatras and the Pieniny (Tobolewski, 1980). The second species - Gyalolechia fulgens occurs also in southern Sweden (Santesson, 1993) and, after a large gap in the range, in the southern uplands of Poland and in the west of Poland, i.e. on the lower Oder (Wójciak, 1987; Fałtynowicz, 1992).

According to Ceynowa-Giełdon et al. (2004), Squamarina lentigera occurs in two nature reserves located in close proximity: "Ostnicowe Parowy Gruczna" - on the left bank and "Zbocza Płutowskie" - on the right bank of the Vistula River, at remote sites located (similarly to the above-mentioned species from the genus Gyalolechia) more than 250 $\mathrm{km}$ from their nearest localities in southern Sweden and in southern Poland. Furthermore, Squamarina lentigera (like G. fulgens) occurs also at the lower Oder (Tobolewski, 1980; Fałtynowicz, 1992; Wieczorek \& Schiefelbein, 2014) which, similarly to the lower Vistula, is characterised by relatively high concentration of steppe vegetation.

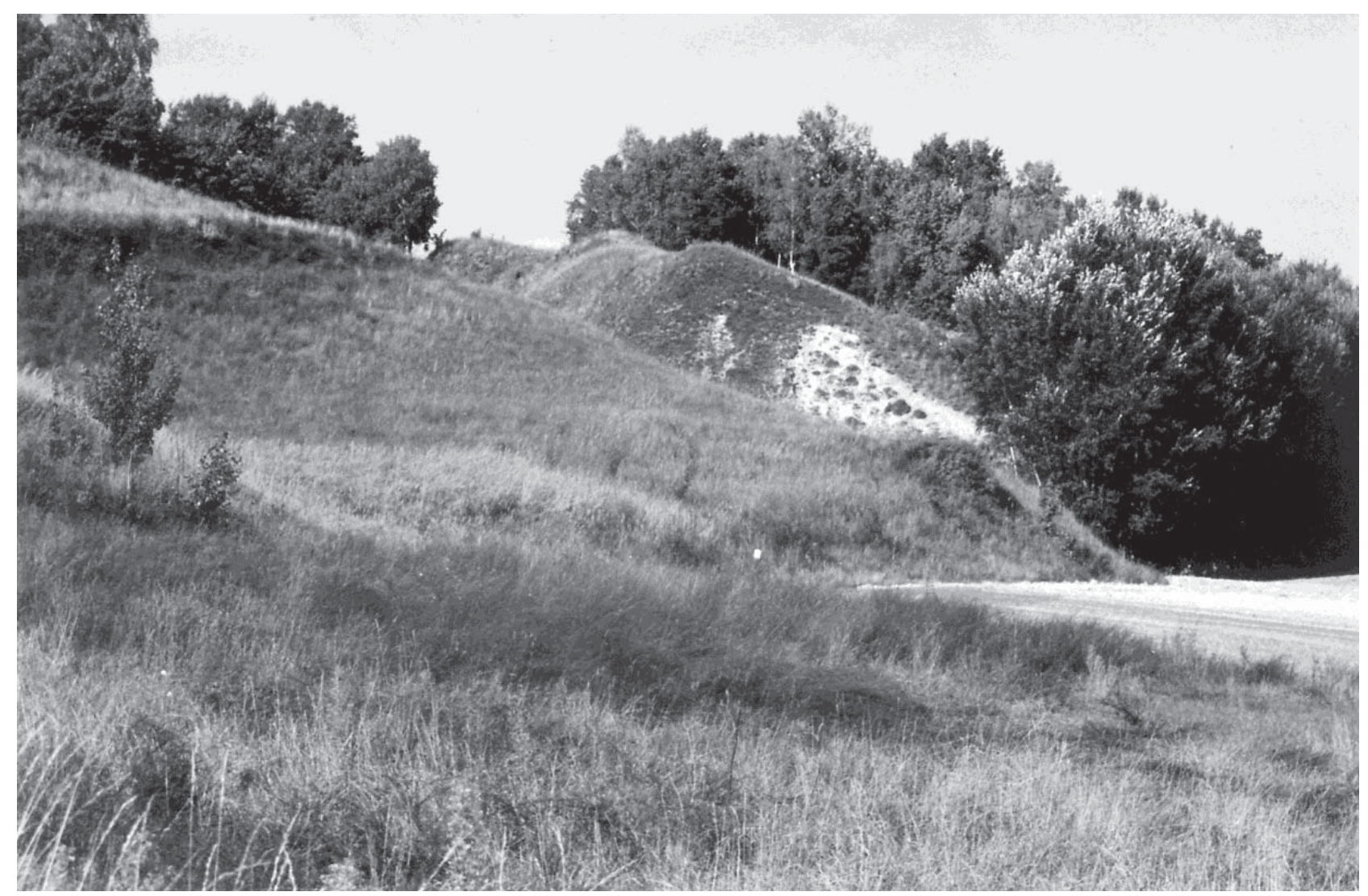

Phot. 1. View of the southern part of the nature reserve "Ostnicowe Parowy Gruczna" with eroded slope and relict locality of lichens (photo by D. Kamiński) 
Toninia sedifolia occurs at the largest number of sites (Fałtynowicz 1992), but those located at the lower Vistula River gradually disappear.

According to Drehwalt (1993), Toninio-Psoretum decipientis is an association characterised by a discontinuous continental range, extending from southern Scandinavia (Öland) to the Mediterranean area. It appears that habitats similar to those in Gruczno occur also in many places along the slopes of the Vistula River valley, but the survival of lichens from the earlier climatic periods was determined by i.a. configuration of the slopes, because the lichens in question clearly respond to soil transformation. They are absent in places on the Vistula River valley slopes where intensive surface runoff of fertilizers from plateau arable fields occurs. As a consequence, they survived mostly in the "Ostnicowe Parowy Gruczna" reserve. The slope with phytocoenoses of Toninio-Psoretum decipientis fulgensietum bracteatae has a shape of a headland isolated by an erosional cleft. In addition, two conspicuous "humps" occur in its upper part, which inhibit the runoff from the plateau, owing to which the water enriched with nutrients flows sideways and clearly bypasses the clusters of relict lichens (Fig. 2).

Nevertheless, the site in Gruczno has been affected to some extent by eutrophication. Unlike Toninio-Psoretum from gypsum and limestone in Saxony, phytocoenoses in Gruczno are characterised by higher contribution of nitrophilous species. Thalli of Blenothallia crispa, often with
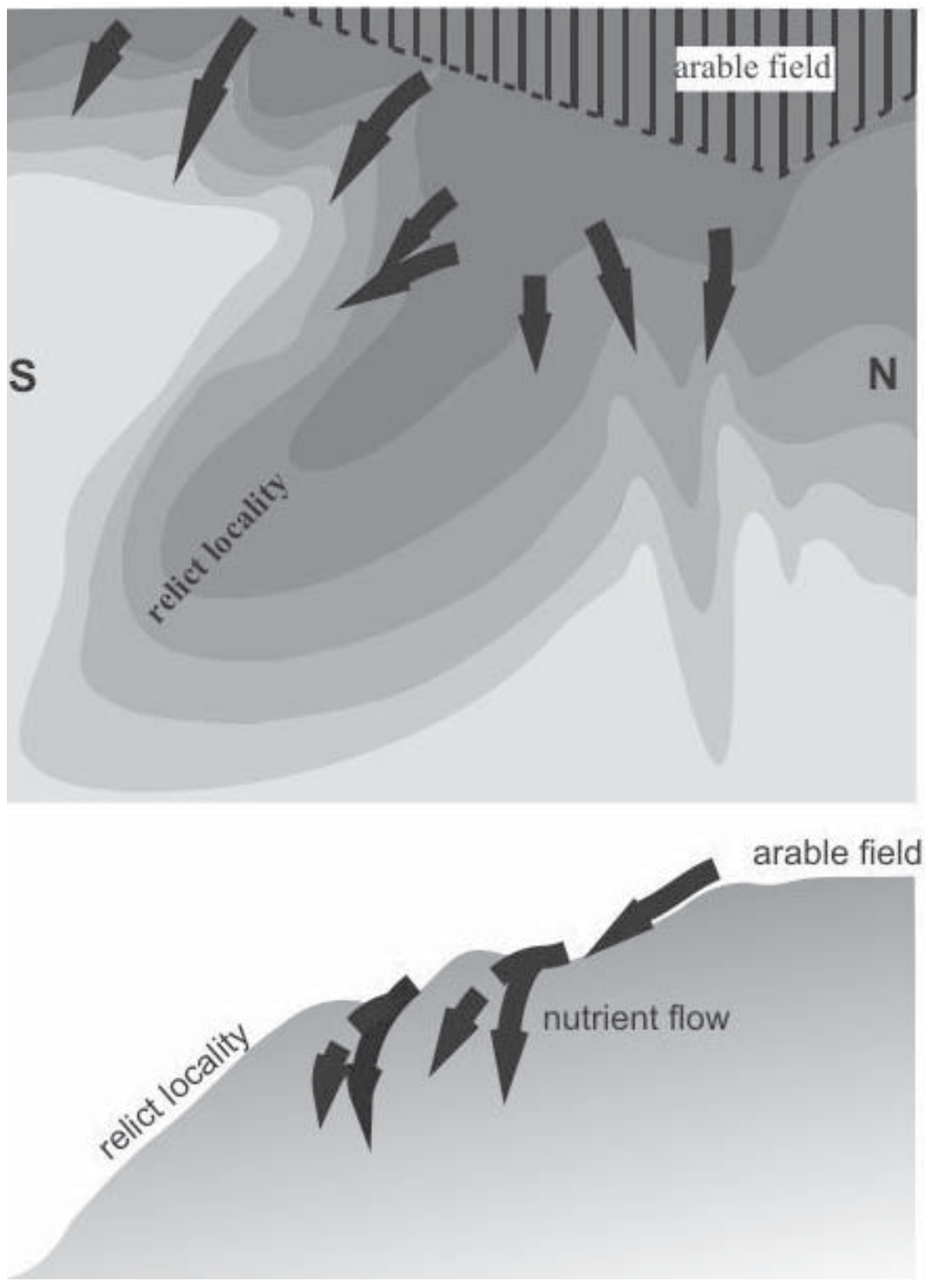

Figure 2. Diagram of geomorphology and direction of the surface runoff of fertile farm water on the slope with the relict locality of epigeic lichens 
attached Endocarpon pusillum, play a particularly important role there. Enchylium coccophorum and in more humid places E. limosum are encountered less frequently. It appears that the runoff of fertilizers is the main cause of rare occurrence of lichens in xerothermic grasslands of the lower Vistula, because other lichens of thin grasslands also occurs mostly in places isolated from the direct runoff from arable lands. Lichens were not found in highly synanthropic places, for example on the hillfort in Kałdus ("Góra św. Wawrzyńca" nature reserve) near Chełmno, in well-developed patches of the steppe association Potentillo-Stipetum capillatae (Ceynowa-Giełdon et al., 2004).

A similar situation occurs in thermophilous, anthropogenically malformed grasslands in Folusz (Adamska \& Adamski, 2014; Nienartowicz et al. 2014).

\section{Conclusions}

Lichens associated with the relict steppe vegetation are the most interesting group among lichens encountered in the lower Vistula valley. It is presumed that some of these species have survived on the slope of the Vistula River valley, as did the relict species of vascular plants, since the first woodless postglacial periods. This was possible due to specific habitat conditions and erosion processes, which expose fresh layers of soil and the activity of man who transformed primeval forest areas into grazing lands. However, the sensitivity of lichens to the effects of human economy is greater compared to vascular plants.

Lichens associated with xerothermic grasslands become extinct despite the optimum light conditions and they are only able to survive at sites isolated from the surface runoff of fertile farm water.

\section{Acknowledgements}

The authors are grateful to anonymous Reviewers for their valuable remarks and suggestions.

\section{References}

Adamska E. \& Adamski A., 2015, Materials to the lichen biota of the hill in Folusz near Szubin (NW Poland). Ecological Questions 20: 39-44.

Adamska A., Deptuła M, Filbrandt-Czaja A., Kamiński D, Lewandowska-Czarnecka A. Nienartowicz A. \& Sewerniak P., 2015, Heathlands and associated communities in Kujawy and Pomerania: management, treatment and conservation. Toruńskie Towarzystwo Naukowe, Województwo Kujawsko-Pomorskie, Toruń
Ceynowa M., 1969, Zbiorowiska roślinności kserotermicznej nad dolną Wisłą [Xerotherme Pflanzengesellschaften an der intern Wisła]. Studia Soc. Torunensis, Toruń - Polonia, Sec. D (Botanica) 8(4): 3-155.

Ceynowa-Giełdon M., 1993, Porosty z rodzaju Collema nad dolną Wisłą. Acta Mycologica 28(1): 53-59.

Ceynowa-Giełdon M., 1997, Collema bachmanianum (Lichenes, Collemataceae) - porost nowy dla lichenoflory Polski [Collema bachmanianum (Lichenes, Collemataceae) - a new lichen species in Poland]. Frag. Flor. Geobot., Ser. Polonica 4: 345-349.

Ceynowa-Giełdon M., 2001, Kalcyfilne porosty naziemna na Kujawach [Calciphilous terricolous lichens in $\mathrm{Ku}-$ jawy]. Wyd. Naukowe UMK, Toruń.

Ceynowa-Giełdon M. \& Glazik N., 1994, Rzadkie porosty kserokontynentalne na obszarze dolnej Wisły [Rare xerocontinental lichens in the Lower Vistula region]. Frag. Flor. Geobot., Ser. Polonica 1: 41-47.

Ceynowa-Giełdon M., Adamska E. \& Kamiński D., 2004, Porosty w dolinie dolnej Wisły i na obszarze przemysłowym Kujaw [Lichens of the Lower Vistula and the Kujawy industrial area], [in:] E. KrasickaKorczyńska, M. Korczyński (eds), Wycieczki geobotaniczne. Region Kujawsko-Pomorski [Geobotanical excursions. The Kujawy-Pomerania Region]. Wyd. Polskie Towarzystwo Botaniczne Oddział Toruński, Oddział Bydgoski, Wyd. Uczelniane ATR, ToruńBydgoszcz: 13-22.

Ceynowa-Giełdon M. \& Waldon B., 2001, Flora i zbiorowiska roślinne rezerwatu stepowego w Grucznie [Flora and plant communities of the steppe reserve in Gruczno]. Zeszyty Naukowe Akademii Bydgoskiej im Kazimierza Wielkiego w Bydgoszczy, Studia Przyrodnicze 15: 5-96.

Cieśliński S., 1979, Udział oraz rola diagnostyczna porostów naziemnych w zbiorowiskach roślin naczyniowych Wyżyny Kieleco-Sandomierskiej i jej pobrzeży [Contribution and diagnostics significance of terricolous lichens in vascular-plant communities of the Kielecko-Sandomierska Upland and its periphery]. Wyd. WSP, Kielce.

Cieśliński S., 1981, Nowe i bardziej interesujące gatunki porostów na Wyżynie Kielecko-Sandomierskiej i jej pobrzeżach [New and more interesting species of tericolous lichens in the area of the Kielecko-Sandomierska Upland and its periphery]. Frag. Flor. Geobot. 27(3): 527-539.

Cieśliński S. \& Czyżewska K., 1992, Problemy zagrożenia porostów w Polsce [Problems of threatened lichenized fungi in Poland]. Wiad. Bot. 36(1-2): 5-17.

Cieśliński S., Czyżewska K. \& Fabiszewski J., 2006, Red list of the lichens in Poland, [in:] Z. Mirek, K. Zarzycki, W. Wojewoda, Z. Szeląg (eds), Red list of plants 
and fungi in Poland. W. Szafer Institute of Botany, Polish Academy of Sciences, Kraków: 71-89.

Drehwald U., 1993, Die Pflanzengesellschaften Niedersachsens - Bestandsentwicklung, Gefährdung und Schutzprobleme - Flechtengesellschaften. Naturschutz und Landschaftspflege in Niedersachsen 20(10): $1-122$.

Fałtynowicz W., 1992, The lichens of Western Pomerania (NW Poland). An ecogeographical study. Polish Bot. Stud. 4: 1-182.

Fałtynowicz W. \& Kossowska M., 2016, The lichens of Poland. A fourth checklist. Acta Botanica Silesiaca, ser. Monographiae 12: 1-122.

Filipek M., 1974, Murawy kserotermiczne regionu dolnej Odry i Warty [The herothermic grasslands of the lower Oder and Warta region]. Pr. Komis. Biol. Pozn. Tow. Przyj. Nauk 3: 3-109.

Glanc K., 1964, Lecidea decipiens (Ehrh.) Ach. i inne interesujące gatunki porostów w murawach kserotermicznych północno-zachodniej Polski [Lecidea decipiens (Ehrh.) Ach. and other interesting lichens in the xerothermic grassplots of northwestern Poland]. Frag. Flor. Geobot. 10(2): 263-267.

Index Fungorum, 2017, http://www.indexfungorum.org [Accessed 2017-03-25].

Löbel S., Dengler J.\& Hobohm C., 2006, Species Richness of Vascular Plants, Bryophytes and Lichens in Dry Grasslands: The Effects of Environment, Landscape Structure and Competition. Folia Geobotanica 41(4): 377-393.

Moberg R. \& Holmåsen I., 1992, Flechten von Nord- und Mitteleuropa Ein Bestimmungsbuch. Gustav Fischer Verlag, Stuttgart Jena New York.

Nienartowicz A., Kamiński D. Kunz M., Deptuła M. \& Adamska E., 2014, Changes in the plant cover of the dune hill in Folusz near Szubin (NW Poland) between 1959 and 2013: the problem of preservation of xerothermic grasslands in the agricultural landscape. Ecological Questions 20: 23-38.

Nowak J., 1961, Porosty Wyżyny KrakowskoCzęstochowskiej [The Lichens of the KrakowskoCzęstochowska Upland]. Monogr. Bot. 11(2): 1-126.

Nowak J. \& Tobolewski Z., 1975, Porosty polskie [The lichen flora of Poland]. Państwowe Wydawnictwo Naukowe, Warszawa-Kraków.

Olech M., 1985, Zbiorowiska porostów w wysokogórskich murawach nawapiennych w Tatrach Zachodnich [Lichen communities in alpine calcareous grasslands in the Western Tatra Mts.]. Uniw. Jagielloński, Rozprawy Habilitacyjne 90: 5-132.

Otte V. \& Rätzel S., 2004, Kommentiertes Verzeichnis der Flechten und flechtenbewohnenden Pilze Brandenburgs. Deutzchland. Feddes Repertorium 115(1-2): $135-154$.
Purvis, O. W., Coppins, B. J., Hawksworth, D. L., James, P.W. \& Moore, D.M.,1999, The lichen flora of Great Britain and Ireland. Natural History Museum Publications in association with The British Lichen Society, London.

Rozporządzenie Ministra Środowiska z dnia 9 października 2014 r. w sprawie ochrony gatunkowej grzybów Dz. U. poz. 1408 [Regulation of the Minister of Environment dated November 9, 2014 on the legally protected fungi, Dz.U. (Journal of Laws) item 1408].

Rozporządzenie Nr 93/99 Wojewody Kujawsko-Pomorskiego z dnia 12 maja 1999 r. w sprawie uznania za rezerwat przyrody pod nazwą "Ostnicowe parowy Gruczna" [Regulation of Voivode of Kuyavian-Pomeranian Voivodeship on the recognition as a nature reserve under the name "Ostnicowe parowy Gruczna"]. Dz. Urz. Województwa Kujawsko-Pomorskiego z 1999 r. Nr 36, item 267.

Santesson R. 1993. The lichens and lichenicolous fungi of Sweden and Norway. SBT - Förlage, Lund.

Schiefelbein U., 2002, Die Flechtenflora des Randowtales zwischen Radewitzer Heide und Schwarzen Bergen (Mecklenburg-Vorpommern). Botanischer Rundbrief für Mecklenburg-Vorpommern 36: 133-154.

Smith C. W., Aptroot A., Coppins B. J., Fletcher A., Gilbert O. L., James P. W. \& Wolseley P. A., 2009, The lichens of Great Britain and Ireland. British Lichen Society, London.

Tobolewski Z., 1962, Materiały do flory porostów północno-zachodniej Polski [Materials to the Lichen Flora of Northwest Poland]. Frag. Flor. Geobot. 8(1): 67-80.

Tobolewski Z., 1958, Porosty Pienin [The Lichen Flora in the Pieniny]. Prace Komis. Biol. Pozn. Tow. Przyj. Nauk 17(5): 1-124.

Tobolewski Z. 1980. Porosty (Lichenes) [Lichens ( $\mathrm{Li}$ chenes)], [in:] J. Szweykowski, T. Wojterski (eds.), Atlas rozmieszczenia roślin zarodnikowych w Polsce [Atlas of the geographical distribution of spore plants in Poland], Seria 3. 6, p.30 + 10 maps. Państwowe Wydawnictwo Naukowe, Warszawa - Poznań.

Wieczorek A. \& Schiefelbein U., 2014, Lichens of xerothermic grasslands in Western Pomerania (Poland). Plant Div. Evol. 130(3-4): 295-302.

Wirth V., 1995, Flechtenflora. Bestimmung und ökologische Kennzeichnung der Flechten Südwestdeutschlands und angrenzender Gebiete, 2 Aufl. Verl. E. Ulmer, Stuttgart.

Wójciak H.,1987, Flora porostów wapiennych zboczy w Dobrem koło Kazimierza Dolnego nad Wisłą [Flora of lichens of limestone slopes in Dobre near Kazimierz Dolny]. Ann. UMCS, C 42(9): 103-109.

Zając A., 1978, Atlas of distribution of vascular plants in Poland ATPOL. Taxon 27(5-6): 481-484. 